\title{
THE DISABLED PEOPLE, A TOOL FOR A RURAL RE-DEVELOPMENT THE CASE OF MARVEJOLS (LOZÈRE, FRANCE)
}

\author{
Franck Chignier-Riboulon, Mauricette Fournier \\ UMR ‘Territoires', Clermont-Ferrand, France \\ franck.chignier-riboulon@uca.fr; mauricette.fournier@uca.fr
}

\begin{abstract}
Marvejols is a small town located in Lozère (France). Traditionally, the region was poor with an agricultural oriented economy. However, by the 1960s a new type of business was launched: the residential care facilities for disabled people, especially in relation to Jacques Blanc, a key person in the organization and development of this business. This economic activity brought jobs and new attractiveness, counterbalancing decline in traditional sectors. Nevertheless, currently, situation is less favourable, and the local players try to find out a new strategy, particularly in relation to diversification. In this study, our main aim was to understand conditions of starting and growing of this business. Moreover, we would like to understand current fragilities and attempts to adapt the economy of the territory. In this way, our students and we have chosen this area in relation to the economic and historical weight of its activity. The organization of field trips and survey was conducted in a comprehensive approach perspective. Therefore, we took account parameters working in this territory, such as strategies, psychologies (individual and collective), networks and identities. Human dimensions are strong, especially in discourses, and our main result is a better understanding of the local situation, with comparisons to close cases (Corrèze, Creuse). Furthermore, the quality of the geographical analysis provides working relations with the stakeholders.
\end{abstract}

Key words: declining rural areas, residential care facilities, disabled people, territorial capital, local development.

\section{Introduction}

Marvejols is a small town (about 5,000 inhabitants in $2014^{1}$ ) located in the département of Lozère, a French administrative level (figure 1). In this case, separating town and département is impossible, a large part of issues is so close. Lozère is located in the South part of Massif Central, an old massif consisting of several mountain ranges and plateaus. This département is considered as one of the most rural in France, in relation to its high rate of farmers and low population, the lowest with less than 77,000 inhabitants in 2014 (Kourdo, 2017), while the median population of French départements is about 525,000 in 2009. Moreover, Lozère is too much isolated to benefit from urban influence, despite the fact that a motorway, the A 75, has been built to open up Massif Central. Certainly, it participates in development process but the daily road traffic stays low.

Within a specific cognitive and collective context (Giddens, 1991), local players built a collective action process (Chignier-Riboulon, 2014). People with disabilities appeared a resource for stakeholders, developing a type of health economy. In the beginning taking people (children overall) from towns and cities was a tradition, but since the late 1960 s, it became a political and economic strategy to counterbalance the population decline and the weakness of agriculture. In this paper, we analyze Marvejols region more precisely. Our geographical perimeter includes both the small urban area ${ }^{2}$ of Marvejols (figure 2) and the close municipalities linked by a strategic network for developing health sector. The total population is low in a French perspective: about 9,000 inhabitants (2014) in the urban area of Marvejols (municipalities are underlined on figure 2) and about 5,300 in the municipalities around (La Canourgue, Saint-Germain du Teil...).

Over decades disabled people were considered as a new opportunity, especially in this South-Western part of Lozère. However, nowadays, the situation is more complex. Changes affect this health business, like new competition with other départements, and local authorities try to diversify the offer, for instance, by attracting and accompanying new households with business micro-projects. Otherwise, communication policies work on image and attractiveness, for example, a 'welcoming territory' or 'an exceptional living environment' according to a leaflet of GévaudanLozère Association, an official organization. Then, we have to separate official discourse and reality.

\section{Materials and Methods}

One of the research focuses on our laboratory is the study of marginalized areas, especially rural, or small towns in rural areas. Therefore, Marvejols presents parameters (economic, social...) of marginalization and decades of endogenous regeneration. In human sciences, results depend, for a large part, on human dimensions, linked to territorial, historical... relations (Ray, 1998, for instance). These ones guide perceptions of development and, more widely, the building of a future. In this way, collective and individual

1 Demographical data are taken from national census, organized by INSEE, the French national agency for statistics.

2 This name has been given by INSEE. It takes the commuting relations between the centre (Marvejols) and the peripherical municipalities when at least $40 \%$ of the working population works in the centre. 


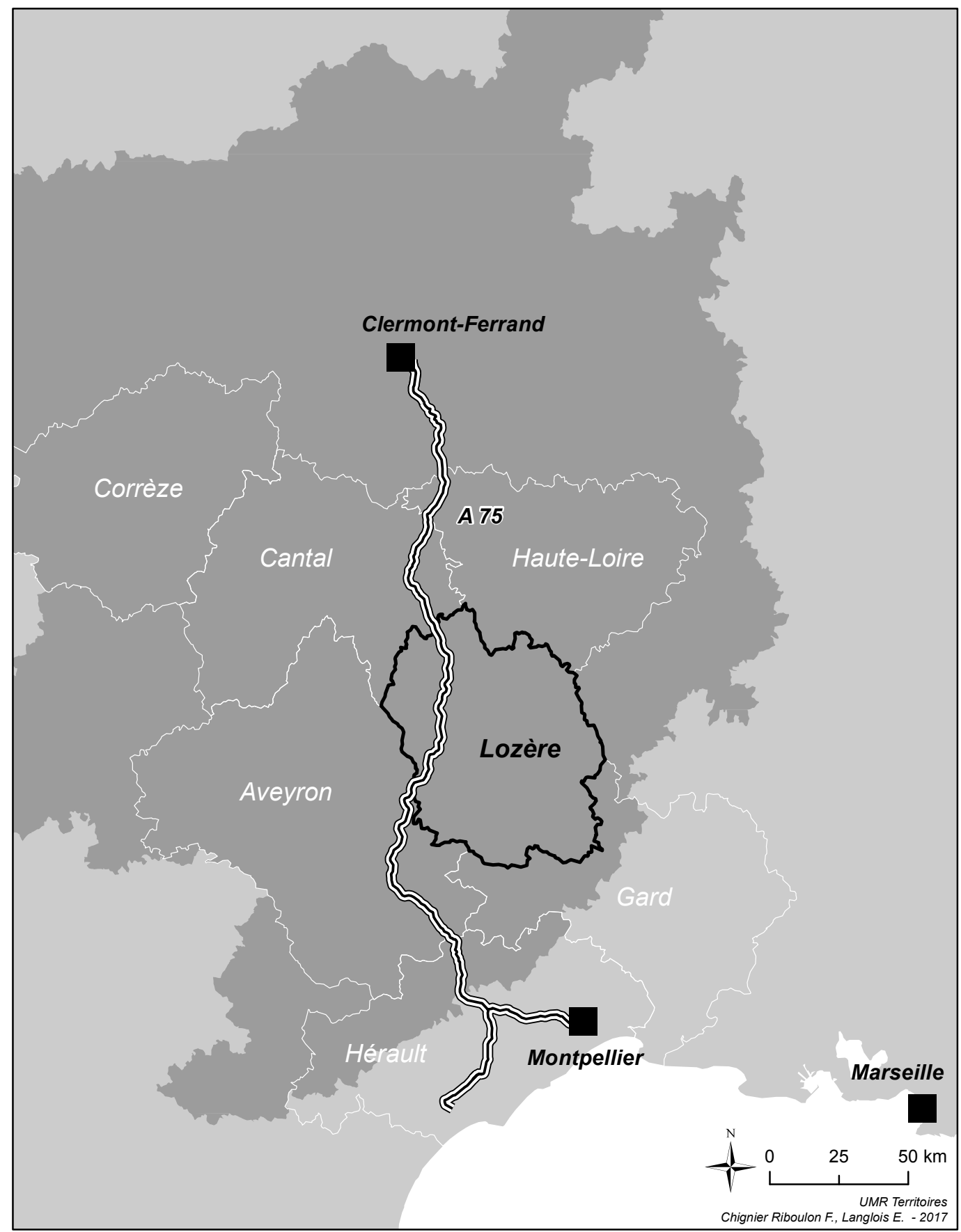

The political cutting of Massif central

$\bar{\equiv}$ Highway $A 75$

Figure 1. Lozère, a French inner periphery.

psychologies are central. Then, even if most of human behaviours have been studied and classified, with their evolution steps, it is very difficult to propose models, because geographical contexts modify analysis. In this study, our main result is the improvement of the understanding of area, for providing better advice to stakeholders. The second result is helping our students to keep analytic distance in research or professional way. For understanding the current weight and logics of the disability business, first we chose a fieldwork. Marvejols was probably the best, in relation to the key role played by this economic branch. Second, we prepared the fieldwork and a survey. The survey was prepared to get information from different types of players on the ground. We have conducted this work in a twofold direction: the first aim was to confront 


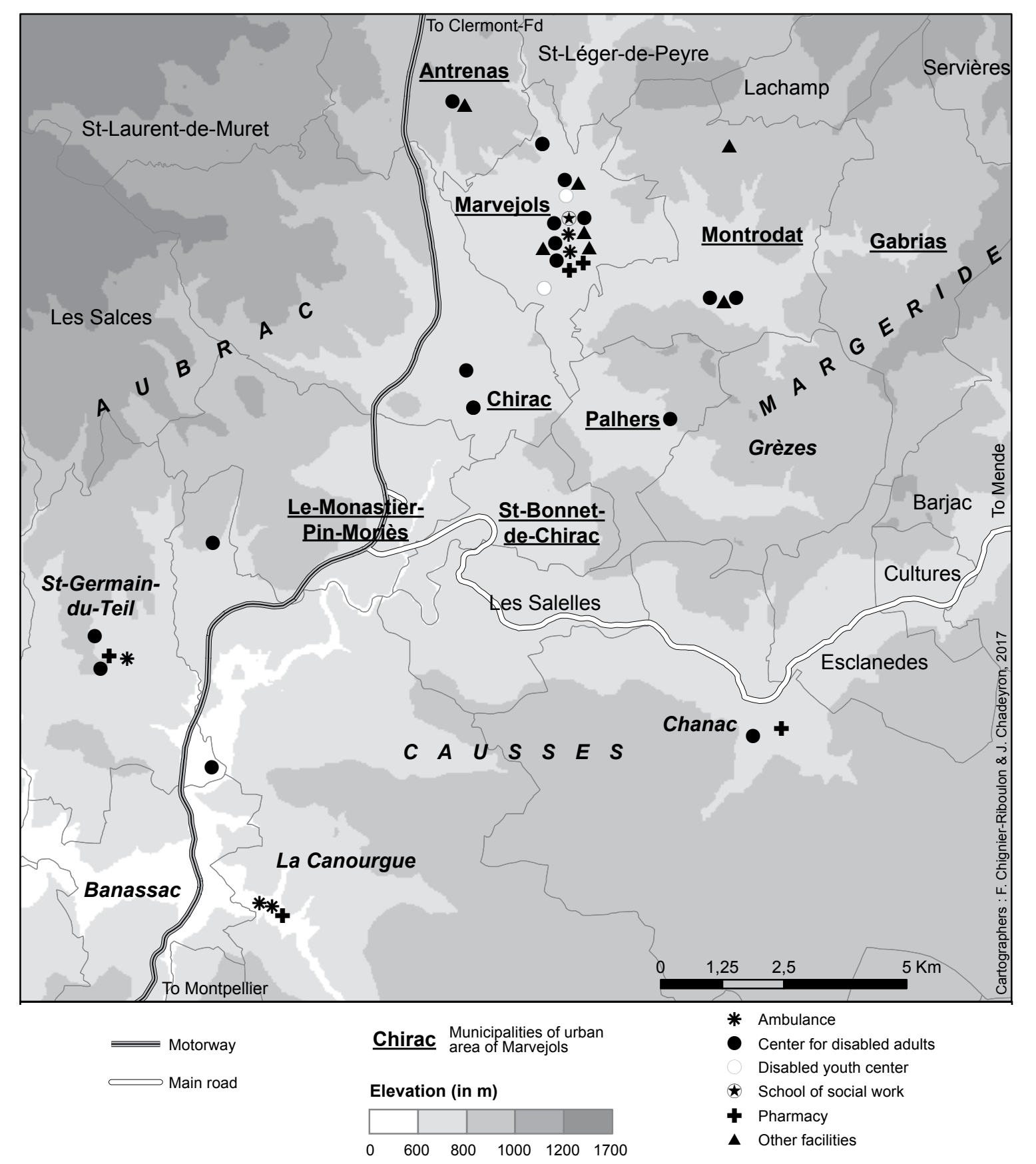

Figure 2. Medico-social facilities in Marvejols mountainous region.

data (mainly from INSEE and from FINESS 3 , the database of the Ministry for Social Affairs) with local observation; the second was in relation to the survey to get discourses and feelings on the current situation and future evolution. Then, the survey was built in a qualitative perspective, focused mainly on people involved in local development. Those are various: politicians, employees of public local structures working for development and planning, managers or employees (nurses, for example) of health structures, small enterprises. More broadly, residents and shopkeepers of the city centre were interviewed. Interviews were semi-open. For officials and managers, their duration was from 45 minutes to more than one hour and a half. Interviews were shorter for inhabitants and shopkeepers, about 10 to 20 minutes. For the first group, questions can be summarized in three categories: the career and life paths of the interviewee, a presentation of the structure with the geographical origins of the employees, and the impact of people

3 FINESS database provides information on every type of health structure. 
with disability on the local economy. For the second, the only one question was on the impact of disabled people on the economy. 56 people were interviewed: 8 politicians, 7 entrepreneurs, 6 shopkeepers, 14 residents, 11 employees of medical amenities and 10 people working in public development structures. Except for shopkeepers and residents, we have met the local key players. The total of people is not so high because population is low, and most discourses are similar in many ways. On key issues most people have no clear idea on flow of working population towards their region or on the economic impact of health structures, but everyone is convinced of their central influence. Moreover, sometimes, interviews were complicated or impossible because this small rural world of high plateau is relatively closed to strangers, and everyone knows each other. Consequently, interviews have been de-identified except for Jacques Blanc; he is now almost retired from politics but was a central, respected, player of the relative regeneration of the region. Finally, if we took appointments with politicians and health structures, we did not do the same with residents and shopkeepers; we asked them directly to try to get information.

This research work was conducted with our students of Master 2 in 2015 and 2016, one week on field in November. For them, this research work was a concrete aspect of research. Beyond the survey they could analyze the geographical dimensions: observation of the distances, social or geographical, comparisons between stakeholders' discourse and their perceptions of the health centres or the city centre, or those of inhabitants.

\section{A Marginal Region, but a Strong Identity}

Lozère experienced a very long period of rural exodus. Traditionally, the agricultural land is in owner-occupation. Nevertheless, soil is often poor and the climate is hard, with long, very windy and snowy winters. The landscape presents high plateaus (figure 2): Margeride (granitic), Causse (calcareous) and Aubrac (volcanic and granitic); most of the population lives in lower lands, close to narrow valleys. Nowadays, forests cover about $48 \%$ of the département, while it was only $10 \%$ in the $19^{\text {th }}$ century (manager of the planning service, $\mathrm{ONF}^{4}$ ), when the peasantry was more numerous, but very poor. In spite of the rural exodus since $19^{\text {th }}$ century, the agricultural working population stays at a high level (12.2\%, Marasovic, 2013), in comparison with the French rate (3.6), ranking Lozère $4^{\text {th }}$ in départements with highest rates (Marasovic, 2013). High rates are considered as factors characterising backward areas. Demographically, the current population is about a half of those of the end of the $19^{\text {th }}$ century (Marasovic, 2012). In the same period, French population was less than 40 millions of inhabitants, and approximately 65 million in 2015. Therefore, the population is more and more aging. The natural increase is negative. The net migration was low over decades and became positive in the last decade, in relation to migrants' flows and the settlement of new inhabitants, often linked to health business. Moreover, the building of the A75 involves a modest development along the motorway, unlocking the region, according to interviewees. In Marvejols urban area and close municipalities, migration has helped to maintain population, and the opening of the A75 facilitates the settlement of households. Interviewees frequently underline this aspect. Also, they underline the issue of keeping young people in this rural area, then they have to find job. Lodging, treating and training people with disabilities provide jobs for youth. The Marvejols region is a kind of inner periphery in France. This situation has perpetuated a strong feeling of territorial identity (di Méo, 2002) and marginality. A declining area like Marvejols tends to reinforce its strong identity, in relation to decades of marginalization and inward looking attitude (Chignier-Riboulon, 2016). Local players worked and continue to do so to support territorial cohesion. If 'Stakeholders are territorialized' (Gumuchian \& Pecqueur, 2007), they are often more territorialized in long term marginalized region (Chignier-Riboulon, 2014). However, local players have used their territorial capital by founding a new axis of development. Lacquement and Chevalier (2016) continue the analysis of Putnam (1993) by underlining different dimensions of territorial capital: first, the capacity of community to organize itself co-operation networks; second, the setting up of local governance; third, the building of strategies of development. Networks, governance are based on common interest for a better life and future, belonging Krugman's definition of public asset (1995). These territorial interrelations are embedded (Pecqueur \& Zimmerman, 2004), building a tangle where everyone tries to take advantages, with relations of domination and dependence.

\section{Building a Strong Activity}

The construction of a strong activity is a combination of several elements (Courlet, 2008). Among them, cultural aspects, like social, historical and geographical identity, are central. These elements can be picked up by a local personality becoming a leader, as Georges Frêche, a mayor, in Montpellier (Viala \& Volle, 2010), France, a minister in Mielec (Jarcewski \& Gwosdz, 2007), Poland, or a priest in Benedita (Chignier-Riboulon \& Fournier, 2003), 
Portugal. In Marvejols, housing, educating, training disabled people, and particularly young mentally ill people, started with a priest, Lucien Oziol. Born in 1920, he was a vicar in Marvejols parish and in charge of children. He met François Tosquelles, a psychiatrist, working at Saint-Alban de Limagnole Hospital (North of Lozère), and found out that children stayed with adults in the hospital (Oziol, 1977). Then, he decided to found a specific establishment for young people, in 1956. He named it 'Le clos du nid' and the first implementation was in the municipality of Grèzes (figure 2). One of the most important people for understanding the construction of this economic sector is Jacques Blanc (interviewed on November, $\left.9^{\text {th }}, 2015\right)$. All the other interviewees have mentioned him as a local famous person. He is now retired but continues to be a key player, as he stays the president of the association 'Le clos du nid' and he is still the mayor of the municipality of La Canourgue. He is a neuropsychiatrist and he worked at the 'Clos du nid' in the end of the 1960s. He began a political career and was elected mayor (1971- until now), member of Département Council (1970 - 1988), a member of French Parliament (1973 - 2001). Later, he became president of the Languedoc Region (1986 - 2004) and senator (2001 - 2011). Thanks to his long political career, he took a large part of this specific development focused on disability and participated in its organization. By the end of 1960s, a doctor was a notable in rural areas. By becoming a local official, he used every parameter to develop his project, combining humanity and business, in a 'local integrated development' (Torre \& Vollet, 2016). According to definitions of innovation by Klein (2014), Jacques Blanc has contributed to weave organizational and institutional networks. In these types of declining countryside, everybody knows everybody. Interrelationships are a strong element to mobilize citizens and overall other local officials. Therefore, development of health structures and a very long support from officials are strongly linked. The development created or reinforced networks. First, they are geographical, to involve officials and other leaders (associations, for example). Then, the growth of the branch brought demands of mayors for building a new facility in their municipality. Second, they are social by creating jobs for local people. These jobs weave proximity relations and, slowly, clientelism. Then, leaders emerge and consolidate their power on the territory. Finally, 'resource is a local players' construction' (Gumuchian \& Pecqueur, 2007). Furthermore, Jacques Blanc has worked at different geographical scales. By the early 1970s, he was elected member of the Parliament (1973) and met Valéry Giscard d'Estaing, participating in his presidential campaign. He defended two bills in favour of disability. They were voted on June $30^{\text {th }}, 1975$. The first one was about schooling and training for disabled people, with allowance rates. The second one concerned the creation of different types of medicosocial institutions. The law organized quantitative and qualitative aspects, with legal standards, and funding. More importantly, he proposed a clause, called 'original place of residence'. It implies that the cost of medical and social cares are financed by the département where the person lived before arriving at a residential care facility in Lozère. Thus, medico-social institutions in Lozère benefit from funding provided by central State or other départements. According to Jacques Blanc, Lozère was a pioneer, and Marvejols region was the first for building working centres for disabled people. He also considers the central position of this activity in local economy: 'Without medicosocial sector, Lozère would not exist'.

\section{Central Position in the Local Economy}

The national scale presents strong inequalities between French départements. According to Rapegno \& Ravaud (2015), working on disabled adults, interdepartemental disparities are from 1 to 40 . The two authors have analyzed the evolution since 1981: Lozère has increased by more than 4 the number of medico-social institutions whereas its population is about the same. Therefore, last data indicate a national average rate of 2.71 beds for 1000 inhabitants. The rate is 10 times more for Lozère. The second département (Corrèze, figure 1) has a rate of $9.75 \%, 18$ points less; so, the authors have created a specific statistical class for Lozère (Rapegno \& Ravaud, 2015).

Consequently, the employment depends directly or indirectly on this growth. Direct jobs are evaluated to 4,500 in Lozère (Marasovic, 2013). The Marvejols region is the most important place for this economic sector. About 2,000 to 2,800 direct jobs are in relation to medico-social (according to estimates of politicians and managers of structures). Currently (FINESS, 2017), 33 medico-social structures work with disabled people (figure 2), and most of the interviewees speak about the strategic position of this sector: "no more Lozère without medico-social economy'. The biggest enterprise, the association 'Le clos du nid', employs 839 people full time and about 200 part time. The firm offers 1,034 beds and manages 21 health structures in different sites, in and outside Marvejols; its turnover was 59 millions of euro in 2015 (head and managers of the association).

Beyond direct jobs and activities, the sector provides a local business. Several small enterprises are linked to these establishments: for instance, ambulances and pharmacies. 5 pharmacies are located in the region and it is too much for the population of local municipalities. In Marvejols, the two pharmacies employ 13 people and may be considered important; 
a large part of the turnover is provided by the orders of health structures. Indirect jobs are also numerous: garages, maintenance, road and construction works and a large part of craftsmen live thanks to the medicosocial sector. This pool of jobs has contributed to maintain public services, like schools, and to save local markets, such as land or real estate ones. The unemployment rate is low, about $6.4 \%$.

Moreover, one of the first aims was to attract households and professionals from outside the départment to counterbalance demographical decline. Henceforth, département and Marvejols region provide more jobs than residents, then net migration was positive in the 2000 s, about 10,000 people came and 3,000 stayed between 1999 and 2009 (Marasovic, 2013). Therefore, a survey of INSEE (Marasovic, 2012) and the interviewees give us elements on new inhabitants. Most of them come from neighbourhood Départements, especially from Gard or Aveyron (Figure 1) to work in social, medical and education sectors and in the related branches. More widely, a part of the highest skilled jobs, as doctors, are held by French people coming from elsewhere, or by foreigners.

\section{Towards an Integrated Centre}

Beyond residential care facilities and humanity, disabled people are also a resource for local development, and local stakeholders consider the organization is close to a cluster model. According to Claude Courlet (2008), a cluster presents an economic specialization, with enterprises with distinct skills providing a complementarity process. Firms are usually numerous and small with relations based on competition and a formal (or informal) co-operation. Certainly Marvejols region has got similarities, but situation is quite different: political leaderships and lobbying are central; main enterprises are integrated in public or social sector; competition is not the main dynamics, but social and political networks, even if, in clusters, political dimension contributes to reinforce or perpetuate the economic system.

However, local players continually worked to develop a wide medico-social sector, and tried to adapt it for capturing and controlling the market. At the beginning, in the 1970s and 1980s, the main aim was to offer a response to the social demand. After this period, the objective was to create the need, by studying society evolution. Consequently, they built an enlarged offer, more and more complete. Therefore, the youth was slowly replaced by adults. By 2016, only $10 \%$ of the residential population were less than 18 years old (according to heads of structures). The idea, humanitarian and economic, was to accompany people along their life until the end. During decades, children were taken and when they were of age, there was no solution for them. Providing solutions for adults and later for seniors was also a strategy to keep the resource in the territory. Then, new services were organized and built: a school to train social workers or a facility for high-level sportsmen with disabilities.

\section{Weakness and New Adaptation}

Medico-social sector in Marvejols region has almost become a mono-industry, but collective representations slowly have changed the look on disabled people. Since the 1990s and moreover the 2000s, sociological and, later, political speeches have been modified. Therefore, proximity is the current dominant idea. In this field, proximity is understood as closer relations with family. Then, geographical proximity has become a necessity. The bill $\mathrm{n}^{\circ} 2005$ 102 (February, $11^{\text {th }}, 2005$ ) encourages creation of new spaces and beds in other French départements. The official policy incites to rebalance. Otherwise, more than $80 \%$ of the disabled people in Marvejols come from other départements. Moreover, this economic activity depends strongly on public expenses. ARS (French central public administration organizing health policy in regions) services in the département precise about 65 million euro are transferred by social security in Lozère facilities for people with disabilities. This issue is important and redistributing these social funds across départements will be a loss for Marvejols and Lozère. In addition, situation becomes more difficult and complex: central government decided to decrease the total of Administrative regions by creating larger ones. Then, Lozère population represents a smaller rate in the new one, Occitanie. In particular, Occitanie size is $73,000 \mathrm{~km}^{2}$ with 5.7 million inhabitants; Lozère only represents $1.35 \%$ of the total population, and its influence risks to decline. Every interviewee spoke about this issue.

To resist and adapt to the current economic system, local stakeholders use different types of strategies. First, the traditional lobbying of politicians: they argue Lozère is a part of "Hyper-rural" such as it has been definite in Bertrand's report (2014), the senator of Lozère, and everyone considers reducing this business is a danger for Lozère. The second response is based on an improvement of services and buildings (refurbishing). For instance, 'Le clos du nid' spent 7 million in this way in the last years. The third one is to provide better services and to complete them by new ones. The objective is to work on quality because quantity is stopped. For example, public policy supports Equiphoria, a centre using horses for autistic people, or it builds a high level centre for athletes with disabilities in Montrodat. For this last case, they hope to get the preparation of athletes for paralympic games. The idea is "to be and to stay at the forefront" (Jacques Blanc) with a permanent innovation capacity. 
The diversification of the local economic activity is the fourth. Para-public associations or agencies ('Lozère nouvelle vie', 'SoLozère'...) work to attract new households. They support them to finalize their business plan or project, and they help them to settle, as in other declining départements of Massif Central, like Cantal or Haute-Loire (figure 1). This policy for attracting new inhabitants receives grants from EU (Leader program). Furthermore, an incentive policy was launched in 1996 (called ZRR, Revitalization for Rural Zones) to support declining rural areas: new enterprises have no tax on profits and land (for at least five years).

Nevertheless, situation remains fragile, the slowdown in net migration since the beginning of the 2010s (Canonéro \& Marasovic, 2016; Kando, 2017) involves a stagnation of the Lozère population, because natural growth continues to be negative. Fortunately, the situation in Marvejols region is a little bit better with a slow densification of the population along the motorway.

\section{Conclusions}

Lozère and especially Marvejols region developed an opportunity linked to health business, the long- term treating and training of people with disabilities. This economic sector has brought value-added and jobs; but finally it has almost become a mono-industry and dependence stays strong. Probably, in spite of adaptations, the sector and the territory have marked a turning point. Local players try to develop new attractiveness linked to well-being branch (close to health) or, more widely, to quality of life in Lozère. However, results are mixed and competition on quality of life is strong, particularly in Massif Central. Forecasts for the future stay difficult.

Marvejols was a good place (demographical size, marginality, former and current economic development policies) for analyzing social psychology, stakeholders' representations and communication policies. The study and, especially, the fieldwork, with the interviews and observations, provide a better understanding of the local issues and representations. Therefore, the diagnostic has brought new perspectives for organizing development and governance.

\section{Acknowledgments}

We would like to thank our students of Master 2.

\section{References}

1. Bertrand, A. (2014). Hyper-ruralité (Hyper-rurality). Report ordered by the prime minister for the minister of housing and territorial equality. Paris: la Documentation française. (in French).

2. Caronéro, B., \& Marasovic, P. (2016). Panorama de la Lozère. Essoufflement de la dynamique démographique (Overview of Lozère. Slowing in population growth). INSEE Analyses. 3(13). INSEE Occitanie. Retrieved March 18, 2017, from: https://www.insee.fr/fr/statistiques/1908404. (in French).

3. Chignier-Riboulon, F., \& Fournier, M. (2003). Emergence et affirmation d'une petite ville industrielle: Benedita (Portugal) (Emergence and growth of a small industrial town: Benedita, Portugal). In C. Jamot \& J.C. Edouard (Eds.), L'avenir des petites villes (pp. 17 - 190). Clermont-Ferrand: Presses de l'Université Blaise Pascal. (in French).

4. Chignier-Riboulon, F. (2014). Les ressorts psychosociaux du changement: des éléments fondamentaux difficiles à actionner (Psycho-social change dynamics: difficulties to operate these key elements). In G. Wackermann (Ed.), Production systems changes in France (pp. 178 - 187). Paris: Ellipses. (in French).

5. Chignier-Riboulon, F. (2016). La France des marges, un objet géographique protéiforme (Margins in France, a proteiform research target). In G. Wackermann (Ed.), La France des marges (pp. 123 - 138). Paris: Ellipses. (in French).

6. Courlet, C. (2008). L'économie territoriale (Territorial economy). Grenoble: Presses de l'Université de Grenoble. (in French).

7. Di Méo, G. (2002). L'identité : une médiation essentielle du rapport espace/société (Identity: a key mediation in the relation between space and society). Géocarrefour, 2(77), 175 - 184. DOI: 10.3406/ geoca.2002.1569. (in French).

8. FINESS. Retrieved March 18, 2017, from: http://finess.sante.gouv.fr/jsp/rechercheSimple.jsp.

9. Giddens, A. (1991). Modernity and self-identity. London: Polity.

10. Gumuchian, H., \& Pecqueur, B. (2007). Les diverses dimensions de la ressource territoriale (Dimensions in territorial resource). In H. Gumuchian \& B. Pecqueur (Eds.), La ressource territoriale (pp. 5 - 10). Paris: Economica. (in French).

11. Jarcewski, W., \& Gwosdz, K. (2007). Du déclin à la reconversion réussie. Le cas de Mielec (Pologne) (From decline to a successful conversion. The case of Mielec (Poland)). In F. Chignier-Riboulon \& N. 
Semmoud (Eds.), Nouvelle attractivité des territoires et engagement des acteurs (pp. 51 - 62). ClermontFerrand: Presses de l'Université Blaise Pascal. (in French).

12. Klein, J.L. (2014). Innovation sociale et développement territorial (Social innovation and territorial development). In J.L. Klein, J.L. Laville \& F. Moulaert, L'innovation sociale (pp. 115 - 147). Toulouse : ERES. (in French).

13. Kourdo, J. (2017). Populations légales au $1^{\text {er }}$ janvier 2014, 76360 habitants dans la Lozère (Legal population in Lozère, on January, $1^{\text {st }}, 2014,76,360$ inhabitants). INSEE Flash. 1(29). INSEE Occitanie. Retrieved March 22, 2017, from: https://www.insee.fr/fr/statistiques/2534574. (in French).

14. Krugman, P. (1995). Development, geography and economic theory. Cambridge, MASS: MIT Press.

15. Lacquement, G., \& Chevalier, P. (2016). Capital territorial et développement des territoires locaux, enjeux théoriques et méthodologiques de la transposition d'un concept de l'économie territoriale à l'analyse géographique (territorial capital and development of local territories, methological and theoretical issues about the transfer of a territorial economic concept to a geographical analysis). Annales de géographie. 5(711), 490 - 518. DOI: 10.3917/ag.711.0490. (in French).

16. Marasovic, P. (2012). Les migrations résidentielles portent la croissance démographique de la Lozère (Residential migrations support population growth in Lozère). Repères synthèse. 10(9). INSEE LanguedocRoussillon. Retrieved March 22, 2017, from: http://www.insee.fr/fr/insee_regions/languedoc/themes/ synthese/syn1306/syn1209.pdf. (in French).

17. Marasovic, P. (2013). La Lozère se revitalise (Demographical revitalization in Lozère). Repères synthèse. 10(6). INSEE Languedoc-Roussillon. Retrieved March 22, 2017, from: http://www.insee.fr/fr/insee regions/languedoc/themes/synthese/syn1306/syn1306.pdf. (in French).

18. Oziol, L. (1977). Les enfants de Saint-Nicolas (St. Nicholas' children). Paris: Robert Laffont. (in French).

19. Pecqueur, B., \& Zimmermann, J.-B. (2004). Les fondements d'une économie de proximités (Basis of proximity economy). In B. Pecqueur \& J.B. Zimmermann (Eds.), Economie de proximités (pp. 13 - 41). Paris: Lavoisier. (in French).

20. Putnam, R.D. (1993). Making democracy work: civic traditions in Modern Italy. Princeton, NJ: Princeton university press.

21. Rapegno, N., \& Ravaud, J.-F. (2015). Disparités territoriales de l'équipement français en structures d'hébergement pour adultes handicapés et enjeux géopolitiques (Geopolitical issues on territorial disparities on French residential care facilities for disabled adults). L'Espace politique. 2(26). DOI: 10.4000/espacepolitique.3447. (in French).

22. Ray, C. (1998). Culture, intellectual property and territorial rural development. Sociologia ruralis. 38(1), $3-20$.

23. Torre, A., \& Vollet, D. (2016). Aux fondements du développement territorial (About basis of territorial development). A. Torre \& D. Vollet (Eds.), Partenariats pour le développement territorial (pp. 11 - 32). Versailles: éditions Quae. (in French).

24. Viala, L., \& Volle, J.-P. (2010). La quête d'une dimension métropolitaine (The search of a metropolitan size). In J.-P. Volle, L. Viala, E. Négrier \& C. Bernié-Boissard (Eds.), Montpellier, la ville inventée (pp. 10 - 29). Marseille: Parenthèses. (in French). 